\title{
Policy Issues in NEG Models: Established Results and Open Questions
}

\author{
Pasquale Commendatore ${ }^{1}$, Christoph Hammer $^{2}$, Ingrid Kubin ${ }^{2(\bowtie)}$, \\ and Carmelo Petraglia ${ }^{3}$ \\ ${ }^{1}$ Department of Law, University of Naples "Federico II", Naples, Italy \\ commenda@unina.it \\ 2 Department of Economics, \\ Institute for International Economics and Development, \\ WU Vienna University of Economics and Business, Vienna, Austria \\ \{Chris toph. Hammer, Ingrid.Kubin\}@wu. ac.at \\ 3 Department of Organization and Economics of Institutions, \\ University of Basilicata, Potenza, Italy \\ carmelo.petraglia@unibas.it
}

\begin{abstract}
This paper provides a non-technical overview of NEG models dealing with policy issues. Considered policy measures include alternative categories of public expenditure, international tax competition, unilateral actions of protection/liberalisation, and trade agreements. The implications of public intervention in two-region NEG models are discussed by unfolding the impact of policy measures on agglomeration/dispersion forces. Results are described in contrast with those obtained in standard non-NEG theoretical models. The high degree of abstraction limits the applicability of NEG models to real world policy issues. We discuss in some detail two extensions of NEG models to reduce this applicability gap: the cases of multi-regional frameworks and firm heterogeneity.
\end{abstract}

Keywords: New economic geography $\cdot$ Agglomeration • Economic integration · Tax competition $\cdot$ Government expenditure $\cdot$ Trade agreements

\section{Policy Issues in NEG Models: A General Discussion}

\subsection{NEG Models in a Nutshell}

In his seminal contribution, Krugman (1991) presented an intriguing and most stimulating argumentation: even if countries were identical, an uneven distribution of economic activity may emerge endogenously. The central mechanism is the following: Assume two identical regions that produce a homogenous agricultural commodity and differentiated manufacturing commodities. Markets for manufactured goods are monopolistically competitive (in the standard Dixit-Stiglitz set up with decreasing average costs in production and a love for variety utility function); trading commodities between regions is possible, but involves trade costs (that do not occur when selling commodities in the local market). In that environment, firms that have access to a larger local market have higher profits and are able to pay higher wages. Higher factor rewards, in turn, attract factor migration towards this region (or trigger more intense capital formation). 
If migration is combined with a relocation of commodity demand, the local market size increases, which leads to even more migration - agglomeration is the result of a self-reinforcing factor migration process (or in some model variants of a self-reinforcing process of capital formation or firm entry). In models in which the mobile factor are workers, this so-called market size effect is enhanced by a price index effect. Variety loving consumers buy all commodity variants - irrespective of whether they are produced locally or imported. Therefore, the respective consumer price index is lower in the region in which more variants are produced locally (that do not involve transport costs), i.e. in the region with more firms. Workers thus migrate to the bigger region not only because firms are able to pay higher wages, but also because of the lower consumer price index. A competition effect works against these two agglomerative forces: with more firms in a market, the market niche of a single firm may shrink, even if the overall market size in that region has increased.

In more recent model variants, the competition effect may be enhanced via a variable mark-up - with more firms in the local market, the mark-up, which each single entrepreneur may charge, is reduced. Note that the last effect requires a departure from the standard Dixit-Stiglitz modelling of monopolistic competition. In these models, the CES utility function (giving rise to iso-elastic demand functions) is replaced by a log-linear utility function (that gives rise to linear demand functions implying varying mark-ups for monopoly pricing).

NEG models typically show that the competition effect dominates for high trade costs and an even regional distribution of economic activity emerges. Instead, agglomeration forces prevail for lower trade costs and a core-periphery pattern of economic activity appears. Given the symmetry of regions, agglomeration can appear in either of the two regions. In many models, both types of equilibrium co-exist as (locally) stable fixed points for intermediate levels of trade costs. In that case, small shocks may trigger a self-reinforcing process leading from a symmetric industry distribution to a core-periphery pattern. The direction of the small shock determines which region gets the core. In more technical terms: both types of equilibria have their own basin of attraction and small shocks can push the economy from one basin of attraction into the basin of attraction of another equilibrium. Thus, history matters for the long-run evolution of economic activity, which is an often-reiterated theme of NEG (see Krugman 1992). Another implication of the multiplicity of coexisting equilibria is that an economic evolution may not be reversible and hysteresis phenomena occur in the spatial pattern of economic activity.

The change in the locally available quantities of productive factors is at the core of each NEG model. Therefore, it is very common to classify models according to the mobility assumptions (see Baldwin et al. 2003; Brakman et al. 2001). We will use this classification also in this chapter:

Core-periphery model (CP, see Krugman 1991): Workers are mobile between regions but not between sectors. Since worker spend their income locally, demand is mobile as well.

Footloose entrepreneur model (FE, see Forslid 1999; Ottaviano 2001; and Forslid and Ottaviano 2003): Entrepreneurs (with their knowledge capital) are mobile between regions (but not between sectors). Entrepreneurs spend their income locally; therefore, demand is mobile as well. 
Footloose capital model (FC, see Martin and Rogers 1995): Manufactured goods require entrepreneurial knowledge capital (blueprints). While capital is mobile between regions in search of the highest nominal reward, it is assumed that the capital earnings are remitted back to the owner who is regionally immobile. Hence, in that model class, factor mobility does not lead to a relocation of demand, which considerable simplifies the analytics, at the cost of losing some of the core features of a NEG model.

Constructed capital model (CC, see Baldwin 1999): There is no factor mobility between regions. However, capital is accumulated (constructed), possibly at different rates in both regions, which also may lead to agglomeration.

Vertical linkages model (VL, see Venables 1996; and Krugman and Venables 1995): This model class introduces input-output relations. Workers are not mobile between regions, but between sectors. They may move out of agriculture into newly created input firms, which may lead to a different regional industrial development and to agglomeration.

\subsection{Policy in NEG Models: Fundamental Questions and the Applicability Gap}

The highly abstract model construction with initially identical regions is the sparkling core of Krugman's argument. Even at this very abstract level, policy issues immediately emerge. Multiple equilibria with varying stability properties beg the question whether they are equivalent, viewed through the lens of a social welfare function. In addition, a typical NEG model involves several inefficiencies: most obvious, monopolistic price setting leads to socially inferior outcomes; in a context of imperfect competition, any change in the locally available amount of productive factors involves pecuniary externalities that are welfare relevant. There is a small strand of literature that addresses such questions explicitly: Ottaviano and Thisse (2001), Ottaviano et al. (2002), Ottaviano and Thisse (2002), Tabuchi and Thisse (2002), and more recently Pflüger and Südekum (2008) and Grafeneder-Weissteiner et al. (2015). We would like to point out two interesting results of this strand of literature: a first result relies on the possible multiplicity of equilibria. Those papers show the possibility of over-agglomeration, i.e. a situation in which decentralized market processes without policy intervention lead to agglomeration, while the symmetric equilibrium exhibits a higher social welfare. The papers take this as a basis for regional redistributive policy, either in the form of restrictions on factor mobility (in order to prevent agglomeration) or in the form of interregional transfers to compensate the periphery. A second result focusses on the stability properties: Given the monopolistic set up, the symmetric, stable equilibrium may quite well be inefficient and policy interventions can increase the social welfare (in the symmetric equilibrium). However - and this is the interesting result - these optimal policy interventions may change the stability properties of the symmetric equilibrium that becomes unstable; thus, an allegedly optimal policy intervention may lead to unintended agglomeration.

A related policy topic that already emerges at a very abstract level are distributive issues, which actually are pervasive in NEG models. The utility level of the immobile workers left behind in the periphery is lower than the utility level of the workers in the core region. In such a situation, using a social welfare function is not without problems. 
Charlot et al. (2006) point out that a simple utilitarian social welfare function actually reflects indifference to inequality and the authors suggest using a more general CES specification that allows reflecting various attitudes towards inequality. Charlot et al. (2006) show that the attitude towards inequality heavily influences the result; however, over-agglomeration is a possibility also in their framework.

Leaving these fundamental policy questions aside, prototype NEG models with two initially identical regions are often used to assess the impact of various policy measures including tariffs, free-trade agreements, customs unions, taxes, subsidies, and public expenditures on items such as infrastructure, transport systems, and R\&D - on the regional distribution of economic activity. We review this literature in the following sections. Each section start with the analysis for two regions and, subsequently, we discuss whether the two regions' results carry over to a multi-regional framework (for the latter see Commentatore et al. 2015).

Before proceeding, it is worth noting that the extreme degree of abstraction limits the applicability of NEG models to real world policy issues and that NEG models were extended in various directions to reduce this applicability gap: Many NEG models allow for different country sizes. The admittedly simplistic representation of geography in NEG is a highly disputed issue and several extension are found in the literature. Most recently, some NEG models include firm heterogeneity. We explicitly discuss the last two issues and start with extensions concerning geography.

It was Krugman (1993) who borrowed from Cronon's famous book "Nature's Metropolis: Chicago and the Great West" (see Cronon 1991) the notions of "first nature" and "second nature". First nature regional differences are exogenous to economic activity, e.g. endowment with natural resources, geographical location - centrality, location at the sea, at a river, in the mountains - and geopolitical factors (see also Venables 2006; Roos 2005). First nature asymmetries can easily explain an asymmetric regional distribution of economic activity. However, the main achievement of the New Economic Geography is to show that even when starting with first nature identical regions, endogenous economic - i.e. second nature - processes may bring about a very uneven regional distribution of economic activity. In typical NEG models, first nature geography plays a minimal role. Regions are separated by (symmetric) transportation or trade costs (see also the discussion in Østbye 2010). In the unfolding of the NEG paradigm over the last decades, some contributions do bring back first nature differences and study their interaction with second nature agglomeration processes (for overviews see Fujita and Mori 2005 and Venables 2006). In the next paragraphs, we present two possibilities found in the literature for incorporating first nature differences into NEG models and discuss whether the basic NEG mechanisms are still relevant.

The first approach consists of assuming differences in trade costs, conveying first nature advantages to some regions. Krugman (1993) and Ago et al. (2006) analyse three (or more) regions located on a line, which gives a locational advantage to the middle region. Fujita and Mori (1996) also analyse a multi-region model in which some locations have a first nature locational advantage (e.g. a port functioning as transport hub). Østbye (2010) analyses a two region model in which one region has a first nature advantage because of trade links with an outside region. Differences in the trade costs change the strength of the various agglomeration and dispersion forces. A centrally 
located region has an advantage in accessing markets. However, it is also subject to a stronger competition effect. The papers typically show that second nature forces may dominate first nature advantages. Krugman (1993) and Ago et al. (2006) show that agglomeration may not occur at the geographical center, instead intense competition in the middle region can force manufacturing to move out and agglomeration occurs in more peripheral regions. The typical NEG theme of irreversibility and regional hysteresis resonates in the results found in Fujita and Mori (1996): A region that became the core because of first nature advantages may continue to be core even if it had lost its first nature advantage. An example for this is a natural port that functioned as transport hub and that lost this first nature advantage due to innovations in the transport system.

A second approach to model first nature disparities is to specify productivity differences between the regions (possibly due to regional differences in the endowment with natural resources), i.e. to introduce Ricardian (comparative or absolute) advantages into a NEG framework.

NEG models typically show that for high trade costs both agglomeration (such as market access and price index effect) and dispersion forces (such as the competition effect) are strong. In addition, they typically show that for high trade costs dispersion forces dominate and that an equal regional distribution of economic activity emerges. Instead, for low trade costs, both forces are weaker and agglomeration forces dominate, which leads to a core-periphery pattern of economic activity. Comparative advantages add another dispersion force, since each region attracts industry that uses its specific comparative advantage, the strength of which does not vary with trade costs. Therefore, for low trade costs both NEG forces are weak and comparative advantage dominates, and this leads to a dispersed industry structure. Instead, for intermediate and high trade costs NEG forces dominate. In particular, for intermediate trade costs NEG agglomeration forces shape the regional distribution of industry and its regional specialization (and thus trading) pattern may not follow comparative advantages. For high trade costs, NEG dispersion forces lead to an equally distributed industry, perhaps biased towards comparative advantage (see e.g. Picard and Zeng 2010; Forslid and Wooton 2003, see also the related contributions by Ricci 1999; Bagoulla 2006; Matsuoka and Kikuchi 2012; Pflüger and Tabuchi 2016; and Commendatore et al. 2017). In an interesting related paper, Matsuyama and Takahashi (1998) analyse a two regions model that also includes Ricardian advantages into a NEG perspective. The authors show that allowing for factor migration may overturn the comparative advantage structure; in addition, they explicitly address the above mentioned welfare issues and show that in some cases agglomeration may be socially undesirable.

After having discussed the representation of geography in NEG models, we turn to another direction of increasing the degree of realism: The "new new economic geography" (NNEG, see Ottaviano 2011) loosens the symmetry assumption by introducing firm heterogeneity á la Melitz (2003), i.e. introducing firms that differ wrt productivity. This not only allows asking under which conditions firms or workers chose to agglomerate or disperse across space, but also if more or less productive firms behave differently in this process.

Baldwin and Okubo (2006) are the first to integrate part of the Melitz framework into the FC model. Firm heterogeneity is introduced by different marginal costs for each firm and these differences follow a Pareto distribution. Furthermore, switching 
regions is associated with a quadratic cost function. While the regions are symmetric in tastes and technology, one region is assumed larger in terms of the number of firms and workers. As in the FC model, there is a tendency for firms to move towards the larger region, which is governed by agglomeration forces. Probably not surprising, the most productive firms move first. They can bear the costs associated with moving most easily. Therefore, there is a maximum marginal cost that drives the relocation of firms from the smaller to the larger market. As trade gets freer, more firms find it profitable to relocate to the larger region. The introduction of heterogeneity does not alter the break and sustain points derived in the standard FC model. However, measured in terms of the number of firms, relocation costs combined with differences in productivity act as a dispersion force as fewer firms are able to relocate to the larger market. This leads to a selection effect meaning that only particular firms agglomerate in the equilibrium.

While the FC model is rather simple but lacks some features of other NEG models, Okubo (2009) shows how firm heterogeneity works in the still tractable footloose capital vertical linkages model (FCVL). Symmetric regions additionally allow for the possibility of endogenous asymmetry. Similar to the former paper, Okubo (2009) finds that firm heterogeneity has a moderating effect on the relocation process. In this model, there is a stepwise agglomeration process. The most productive firms that already exported from the smaller region relocate first and stay (net-) exporters. Second, there are firms that sold only locally but become exporters once they relocate to the larger region. Finally, there are firms that only sold locally in the smaller market and that stay a local seller in the larger market. The existence of the last type of firm in the larger region lowers the strength of the agglomeration forces and increases the strength of the dispersion force, the agglomeration process is gradual and only partial. The author also shows that a decrease in the fixed costs that are associated with exporting strengthens the agglomeration forces making full agglomeration a possibility. What is more, he argues that in his model, trade integration leads to a divergence in welfare with the individuals in the larger market being better off.

In a linear setup, Okubo et al. (2010) focus on the role of competition and its relationship to location choice of differently productive firms. Their results indicate that efficient and inefficient firms move away from each other similar to the analysis discussed above. At some point of trade integration, all productive firms are in the larger market, while all less productive firms remain in the smaller market shielding themselves from competition. However, deeper market integration makes it harder for high-cost firms to avoid competition and the agglomeration advantages exceed the competition effect. So there might be a non-monotonic relation between trade integration and the sorting of firms.

By employing a version of the FE model, Ottaviano (2012) demonstrates how firm heterogeneity affects the relative strength of agglomeration and dispersion forces. Entrepreneurs first develop blue prints that are needed for production. Only after observing their productivity do firms decide whether to use them in order to produce. The blue prints depreciate at the end of the period. Similar to the papers before, the model exhibits partial agglomeration when trade barriers fall. The authors pay particular attention to the different effects that a variation of the scale and the shape parameters of the (Pareto) distribution has on the firm selection at the equilibrium. 
Baldwin and Okubo (2014) update their previous work by including entry and exit of firms as well as fixed market entry costs, so-called "beachhead costs". Firms are also able to relocate after their initial location choice or vice versa, they might enter or exit a market after they have relocated.

Incorporating firm heterogeneity into NEG models introduces new and interesting variations of the classic NEG mechanisms. There is still agglomeration and dispersion across space driven by the respective forces. However, agglomeration can be gradual and not every firm is equally likely to move to the larger markets. Thus, in equilibrium, not only the number of firms may be different between regions, but also the distribution of their productivities. This is relevant for welfare analyses. The presence of firm heterogeneity may therefore also alter some policy implications of NEG models.

\section{Public Spending: Productivity and Demand Effects}

NEG scholars have studied the impact of different categories of public expenditure on industrial location within different variants of NEG frameworks. The non-exhaustive survey covered in this section uses the typical distinction between unproductive and productive public spending to classify these models and elaborates on the main channels through which public intervention influences industrial location. In the first case, the government provides an additional channel to the "market-access" effect, via the so-called "demand" effect. Tax revenues are spent in consumption goods, thus financing an additional source of local demand for manufactured goods and magnifying the "market-access" effect. On the other hand, the so-called productive categories of public spending affect firms' location via a "productivity" effect exerted on the supply side of the economy. Investment in $\mathrm{R} \& \mathrm{D}$, transportation and other types of productivity-enhancing infrastructures affect production in the manufacturing sector via their positive impact on factors' productivity.

The first group of works, which includes Trionfetti (1997 and 2001) and Brülhart and Trionfetti (2004), contradict the standard result obtained by Baldwin (1970, 1984) in a Heckscher-Ohlin framework according to which home-bias public procurement is neutral for the determination of a country's pattern of specialisation. Trionfetti (1997) adds public expenditure to a standard two-country/two-region $\mathrm{CP}$ model. To focus on the "pure" demand effect of public expenditure, this author makes two important simplifying assumptions excluding other effects, which could arise from alternative uses of public resources or from taxation policies: The government spends all tax revenues on manufactured goods, which are destroyed after the purchase. Moreover, the income of the mobile factor, i.e. manufacturing workers' income, is not taxed.

The additional public demand for manufactured goods increases local demand. This creates a new demand-linked effect in the model, which can, under certain conditions, dominate all the others and, acting as a dispersion force, may lead to a stable equilibrium with partial spatial concentration and no catastrophic agglomeration. A crucial result is that, by allocating a larger amount of public expenditure to the domestic manufacturing good, for a given level of the expenditure of the other government, a government can enlarge the share of the domestic industry: public expenditure exerts a "pull" effect on the location of industry. Trionfetti (1997) also briefly considers the 
effects of different intergovernmental transfer schemes (pure transfers, tied aid and joint expenditure) showing that these effects depend on how public expenditure is allocated between sectors and domestic and foreign goods.

The above reported result of public expenditure favoring dispersion over agglomeration emerges independently from the employed variant of NEG framework. Trionfetti (2001) and Brülhart and Trionfetti (2004) accommodate for government procurement in the VL version of the CP model (Krugman and Venables 1995). The differentiated manufacturing good is used as an intermediate input by the manufacturing sector itself as well as by national governments for the provision of public services. When public procurement is home-biased, industrial agglomeration cannot occur. One or three long-run equilibria may exist depending on the parameter settings. If countries are identical, the central equilibrium is symmetric and can be either stable or unstable. In the latter case, the industrial sector partially agglomerates in one country (the one with the larger initial endowment of the mobile factor), with the second country keeping some industry: public expenditure exerts a "spread" effect on industry. In Trionfetti (2001), it is also shown that home-biased public procurement may reduce inequalities and, under specific circumstances, be welfare improving. Brülhart and Trionfetti (2004) put forward an empirical analysis aiming to validate the main predictions of their model concerning the "pull" and "spread" effects of home-biased public procurement.

The group of models dealing with the effects of productivity-enhancing public spending includes, among others, Brakman et al. (2002 and 2008) where the FE model is extended in order to include a government sector, which directly produces public goods that may enhance regional competitiveness. Public goods - produced under a constant returns of scale (CRS) technology that uses only variable human capital - are "productive" in that they reduce both fixed and variable costs of manufacturing firms ${ }^{1}$. Brakman et al. (2008) assume that the amount of public capital is fixed; whereas in Brakman et al. (2002), public capital is a share of the overall capital. Another difference between the two models is that in the latter one public goods also affects the individuals' utility function. Two important features of these analyses are as follows. First, the provision of public goods is financed by a uniform income tax. A tax levied also on the mobile factor acts as a spreading force. Second, the effect of public goods on factors' productivity is entirely local, reinforcing agglomeration. The main conclusions of these works are: When equal amounts of public goods are provided in the two regions, an increase of such provision perturbates the equilibrium between agglomeration and dispersion forces, thus fostering agglomeration if sufficiently large. When the provision of public goods in the two regions is asymmetric, numerical evidence shows that the attractiveness of locations is influenced by their endowments of public goods, confirming that the "pull" effect of public expenditure, as partial agglomeration occurs in the region with the larger endowment of public goods. However, if in one of the two regions public expenditure is more effective in reducing production costs or public capital is more efficient in the production of the public good, Brakman et al. (2002) show that even

\footnotetext{
${ }^{1}$ The fixed cost component embodies knowledge-intensive activities such as "R\&D, marketing and management"; whereas both fixed and variable costs are affected by the quality of social and economic infrastructures.
} 
if this region has a lower endowment of public or private inputs it could still attract the larger share of the manufacturing industry. Finally, when cost reduction is sufficiently large to offset the tax increase necessary to finance its production public expenditure may also have a positive impact on the overall number of firms of the economy.

The first group of models, focussing on the demand effect, deliberately abstract from the productivity effect: Typically, public expenditure affects industrial location through demand, while any impact on factors' productivity is neglected as public intervention is not assumed to affect the production function in the manufacturing sector. In the same manner, scholars dealing with the productivity effect deliberately abstract from the demand effect. The contributions by Commendatore et al. (2008, 2009 and 2010) are at the crossroads between these two groups of models as they suggest to jointly study the interplay between the demand and productivity effects of public policy in the same framework.

The framework chosen by Commendatore et al. (2008) is a two-region CC model with mobile capital, which extends the FC model allowing for the endogenous construction/depreciation of capital goods. In the model the asymmetric regional distribution of the immobile factor (labour) between the North (the "rich" or "advanced" region) and the South (the "poor" or "backward" region) translate into different market sizes. The overall economy is composed of four sectors: agriculture, manufacturing, investment sector and government sector. In the investment sector the mobile factor (capital) is produced under perfect competition with a CRS technology involving the use of labour. Capital is used in fixed amounts both by the government (as the only production factor with a CRS technology) and in manufacturing (coupled with the variable labour input). A central (national) government produces a local public good, which enhances labour productivity in the investment and manufacturing sectors. ${ }^{2}$ In this framework the authors address two main questions revealing a possible trade-off between overall efficiency and regional equity: how the provision and the financing of productive public investments impact on the overall stock of private capital and on its distribution across the regions.

An increase in the provision of productivity-enhancing public capital does not always increase the overall private capital as the regional and sectoral distribution of the public investments matters. The "productivity" effect tends to increase private capital, while a "crowding-out" effect between public and private investments works in the opposite direction. Assuming that the investment sector agglomerates where its production is less costly and that the provision of the public good occurs in the other region, the overall capital stock will unambiguously decline due to the "crowding-out effect". On the other hand, if the provision of public goods occurs in the region where the investment good sector is located and the productivity gain in that sector is sufficiently large to overcome the "crowding out" effect, the overall capital stock will increase.

Concerning the effect on the allocation of private capital between the regions, the long-run outcome depends on the combined impact of the two possible effects of public

${ }^{2}$ As in Brakman et al. (2002) the overall capital stock is composed of public and private capital. On the other hand, differently from that contribution, local public goods (public expenditure in research, innovation and education) do not enter in agents' utility. 
expenditure on manufacturing production: the "productivity effect" - a larger provision of public services in one region, by lowering the labour input requirement, attracts firms to that region; and the "demand effect" - the tax rise necessary to finance such provision, by contracting private expenditure for manufactures, induces a non-favorable change in the relative market size, driving away firms from that region. The relevant policy conclusion is that a central government whose aim is to reduce regional inequalities, can choose a suitable financing scheme for public expenditure that could weaken the demand effect inducing firms to relocate in the backward region. The demand effect will be negligible if also taxpayers residing in the advanced region contribute on the basis of their income to the financing. Finally, it is also possible that the provision of public goods in the South could, even in the presence of the "crowding-out" effect, increase the local level of private capital or could improve welfare in that region.

These results are in general confirmed in the much simpler FC setting without investment sector considered by Commendatore et al. (2009), where it is shown that the provision of a productivity-enhancing local public good may redistribute the industrial activity, counterbalancing differences in market sizes between regions. Furthermore, it is also confirmed that the process of agglomeration in the larger region following market integration could be slowed down or even overturned by increasing sufficiently the provision of productive public expenditure.

Commendatore et al. (2010) relax the assumption of pure local effects of productive public expenditure within a FC framework. Focusing on the case of R\&D public expenditure, the authors explore how knowledge creation and diffusion across regions impinges upon the processes of spatial agglomeration and dispersion. The productivity-enhancing effect of public expenditure takes place by lowering fixed costs in the manufacturing sector, so that the number of firms may vary even if the number of capital units is given. Hence, public policy can impact on the endogenous number of firms as well. Two possible scenarios are studied. In the first scenario, knowledge spillovers - in the form of new ideas generated in public universities and research institutions - are (perfectly) global benefitting all firms independently of their location. In this scenario, public policy is able to affect the number of firms as a lower number of these units is required for each variety of the manufactured good: an increase in public expenditure unambiguously increase the total number of varieties. On the other hand, public policy is unable to affect the regional distribution of capital units. However, if the productivity effect is weak, the demand effect can reduce the dimension of the industrial sector in the region that finances public expenditure. In the second scenario, knowledge spillovers are (partially/perfectly) local. The impact of knowledge on productivity gains is spatially limited depending on its local specificity and on the absorbing capacity of firms, so that knowledge generated by R\&D activities benefits firms, which are located in the region where public expenditures occurs. In this scenario, as in Commendatore et al. (2008 and 2009), both productivity and demand effects play a role in determining the equilibrium regional shares of capital as well as the number of varieties produced in each region. Moreover, it is shown that the relationship between the overall number of firms and public expenditure could be non-monotonic. These results hold in the dispersed equilibrium, when the at least some industry is located in both regions. In an agglomerated equilibrium, when industrial sector is concentrated only in one region, the total number of firms always increases 
with public expenditure except in the case of perfectly local spillovers when industry is agglomerated in the region where the R\&D activities do not occur. This conclusion reveals a trade-off between efficiency and equity, which typically emerges in models where the appropriability of knowledge has a spatial dimension.

Recently, so-called new economic geography and growth (NEGG) models introduce a $R \& D$ sector to explain the dynamic processes giving rise to spatial agglomeration and growth. This strand of NEG literature - which jointly considers the spatial and the temporal dimension of the economic development - is mainly based on the endogenous growth models of the Grossman and Helpman (1991) and Romer (1990) type. NEGG models abandon the typical NEG assumption of a fixed stock of resources, bringing to the fore the trade-growth relationship (Martin and Ottaviano 1999; Baldwin et al. 2003; Fujita and Thisse 2002; Dupont 2007; Cerina and Mureddu 2012; and for reviews Baldwin et al. 2003, Chap. 7; Baldwin and Martin 2004; Cerina and Pigliaru 2007; and Breinlich et al. 2014). The main engine of growth is technological change due to $R \& D$ investments and the spatial diffusion of knowledge plays a fundamental role. Moreover, once it is taken into account that knowledge spillovers may exhaust their effect with distance, NEGG models predict a potential trade-off between accumulation and territorial cohesion, giving rise to uneven growth. This extends to the very long-run the government dilemma over the choice between efficiency and equity.

A paradigmatic example of a NEGG model exploring how public policy may impact on agglomeration and growth is the dynamic version of the FC model put forward by Martin and Rogers (1995) and (1998, 1999) and reformulated in Baldwin et al. (2003, Chap. 17). As in Martin and Rogers (1995), in Martin (1998, 1999) public policy may improve intra-regional transport infrastructure - facilitating domestic trade (transport infrastructures, law and contract enforcement and network communications) - and inter-regional/international transport infrastructures - facilitating trade between regions (international communication and transportation system). Moreover, in the presence of partially local spillovers, better transport infrastructures may improve inter-regional knowledge transfer. Envisaging a more advanced region (North) where the investment sector is located and a backward region (South), it is possible to single out the effects of specific policies and study how they can mitigate/exacerbate the trade-off between equity and efficiency: (i) a persistent income transfer to the South reduces income inequality and favours dispersion of the economic activity at the cost of a lower growth rate of the overall economy; (ii) an investment in local (intra-regional) infrastructures in the South may reduce spatial equity at the cost of a larger north-south and capitalists-workers income inequality and a smaller rate of growth of the overall economy; (iii) an investment in (inter-regional) infrastructures favours agglomeration in the North but reduces income inequalities and enhances the growth of the overall economy. Finally, (iv) policies aiming to increase the spatial diffusion of knowledge (such as, investment in telecommunication infrastructures, in internet access or in human capital, and so on) does not suffer the trade-off between equity and efficiency. Indeed, such a policy may reduce both spatial and income inequalities in correspondence of a higher rate of growth of the whole economy.

A limit shared by all the above discussed analyses is that they only consider economies composed of two regions, not allowing for third-region (indirect) effects and complex feedbacks emerging in a multi-region framework or on the role of geography 
(characterizing the accessibility of regions or their endowments of immobile factors or natural resources, and so on) shaping this framework. Indeed, in the words of Desmet and Rossi-Hansberg (2010, p. 44): "[t]he focus on a small number of locations does not allow this literature to capture the richness of the observed distribution of economic activity across space, thus restricting the way these models are able to connect with the data". Thus, according to these authors, the assumption of a small number or regions represents the greatest weakness of NEGG (and a fortiori NEG) models. In various contributions, these authors (see Desmet and Rossi-Hansberg 2009, 2010 and 2014) put forward a theory of spatial development in which space, and therefore the number of locations, is represented as a continuum. Behrens et al. (2007) put forward a study on a spatial network composed of nine regions with a specific geography (part of the network has a tree structure and another a circular structure), clarifying that it is not easy (excepts for specific network configurations) to derive clear-cut general analytic results and therefore to develop the welfare analysis necessary to formulate policy recommendations. In their specific set-up standard results related to preferential trade agreements (which have a global impact over the network) should be better specified taking into account changes in transport infrastructures (whose impact has a more local nature).

The richness of results delivered in multi-region frameworks dealing with the importance of different public policies can be exemplified by referring to the attempts made in the three regions case. Baldwin et al. (2003, Chap. 17) consider an economy where three regions are allocated equidistantly on a line representing a hub-and-spoke economy, where the central region is poor and the two at the borders are rich. They show that the result according to which an increase in interregional infrastructures favors agglomeration in the rich region (Martin and Rogers 1995; Martin 1998 and 1999) is overturned depending on the balancing between the "home market" effect favoring the two rich regions and the "central place" effect giving an advantage to the poor region.

Forslid (1994) confirms that results, which hold in a two-region context cannot always be applied when three regions are considered. This author extends the standard static FC model by introducing three (advanced, intermediate, and poor) regions with different size evaluating how different policies may counterbalance the effects of trade integration. With no policy intervention, at initial stages economic integration leads to deindustrialization in the smaller region (with both the larger and the indeterminate gaining industry) and at later stages to full agglomeration in the larger region (with the intermediate region losing all industry). Relocation of governmental agencies to the periphery, i.e. to one of the smaller regions, could counteract this process. However, if only public capital is transferred to the smaller region, if integration is not complete the reduction of private capital stock in the intermediate region is larger than the stock of governmental capital shifted to the smaller region, thus the net gain for the two peripheral regions following the policy is negative. Relocating public employees as well may advantage both the large and the intermediate region when integration is not too strong. Instead, relocating government capital in the intermediate region may lead to an equal capital distribution between the larger and the intermediate region. Investment in transport infrastructures reducing distance between the larger region and the other two strongly favours the first, which becomes a hub, whereas the smaller peripheral region suffers an acceleration of deindustrialization. The same would apply 
to the smaller region by reducing its distance with the intermediate region. The latter gains all the industry with trade liberalization. Finally, regional subsidies to capital granted to the smaller region financed by a proportional nation-wide labour income tax. This may lead, with partial liberalization, to the disappearance of the industry in the smaller region. However, the smaller region may rapidly reindustrialize when integration progress further.

Such a paradoxical result on the effect of subsidies to poor regions also applies to the case of two asymmetric regions studied by Dupont and Martin (2006) in a static FC model. These authors study the effects of four types of subsidy schemes in a static FC model with two asymmetric regions (again labelled North and South), the first couple designed to encourage firms relocation to the poor region and the second couple to boost production in that region:

(i) a subsidy proportional to (operating) profits granted to firms located in the South financed by a national income tax. This subsidy program determines a shift of the industry to the South (firms relocate where subsidies to profit are supplied) but a worsening of income distribution between workers and capitalists (profit rise in both regions but a larger number of capital owners lives the North);

(ii) a subsidy to profits granted to firms located in the South financed by a local income tax. The signs of the effects just mentioned are the same but the magnitudes are different: the relocation of firms to the South is smaller and the effect upon and income inequality is larger;

(iii) a subsidy to production (and thus to employment) in the South financed by an economy-wide taxation. Higher competition in the labour market induces a rise in wages, income inequalities are reduced and relocation to the South is more pronounced compared to the two previous schemes;

(iv) a subsidy to production in the South financed by local taxation. Since taxes (and higher wages) are paid locally, there is no fiscal transfer from the North to the South. Higher profits are repatriated to the North reproducing the same effects of a subsidy to profits financed locally.

\section{Tax Competition and Agglomeration}

A key conclusion of the traditional tax competition literature is that tax competition leads to a loss of industrial capital to competing countries. This conclusion is based on the following mechanism. Given that capital owners are interested in their after-tax income, assuming that they are taxed according to source principle (i.e. according to the rules specific to the country where income is generated), the comparison of international tax rates will affect and distort international capital allocation. ${ }^{3}$

\footnotetext{
3 A well-known result from the public finance literature is that capital income taxation according to the source principle may lead to a distortionary allocation of capital across countries. Thus, the residence principle, which does not affect capital owners location decisions, is preferable. However, as shown by Commendatore and Kubin (2016) in a NEG framework, once one allows for a different sectoral composition between private and public expenditures, the difference between the two taxation
} 
Producers will move to whichever country has the lowest tax rates and countries will experience falling tax rates in the attempt to attract or hold on productive activities in order to raise local tax revenues. This is in a nutshell the well-known result of the "race to the bottom" of competing governments: countries that try to set a lower tax rate than their neighbors may end up taxing capital income not at all. ${ }^{4}$

As recalled by Andersson and Forslid (2003), key features of tax competition models are: the coexistence of immobile workers and mobile capital, and the question to what extent public goods can be financed by means of taxes on mobile capital. The "race to the bottom" conclusion will imply that taxation of the mobile factor will be distorted downwards compared with a situation where all factors are immobile, thus leading to an inefficient provision of public goods. In this perspective, co-ordination or harmonization of international tax policies is an issue. Typically, tax harmonization entails a shift from a non-cooperative tax game to a cooperative tax game, and Pareto improvement from the government's perspective follows by definition (Baldwin and Krugman 2004).

NEG scholars have shown that this result does not hold in the presence of significant agglomeration economies and goods market integration, and have formally demonstrated that tax competition over mobile productive factors is affected by industrial agglomeration. The general argument rests on the result that increased economic integration leads imperfectly competitive firms (capital owners) to benefit from agglomeration rents that can be taxed. Baldwin et al. (2003) show that such rents arise in a wide range of NEG models. This will allow a country to raise its tax without losing capital and/or its industrial base, thus leading to a "race to the top" rather than a "race to the bottom". As argued by Baldwin and Krugman (2004), wealthier countries offer capital favourable external economies and, within limits, this allows them to hold on to mobile factors of production even while levying higher tax rates than less advanced nations. However, should the tax rate get too high, the results could be catastrophic: "not only will capital move abroad, but because that movement undermines agglomeration economies it may be irreversible" (Baldwin and Krugman 2004, p. 2).

NEG models with public spending (see previous section) often assume some sort of taxation for the financing of public services; however, in that literature, governments typically do not engage in tax competition. In the following, we review models of tax competition involving typical NEG features such as imperfect competition, trade costs and agglomeration rents and thus departing from traditional tax competition analyses.

(Footnote 3 continued)

schemes is less clear-cut. Taxation on the basis of the residence principle is not neutral and may lead to capital relocation; whereas depending on how tax revenues are allocated between manufactured and agricultural goods, the corresponding change in the market size may reduce the distortionary effect of taxation according to the source principle.

4 As summarized by Baldwin and Krugman (2004), the standard tax-competition literature works with a one period model featuring a single good produced by two factors. Labour is immobile between locations and capital is mobile. Trade costs are zero, firms face perfect competition and constant returns, so there is no trade among regions and capital faces smoothly diminishing returns. Typically, governments choose the capital tax rate in a Nash game. The standard approach is to compare equilibrium tax rates with no capital mobility and with perfect capital mobility. The standard result is such that equilibrium taxes are sub-optimally low. 
While the tax competition and agglomeration literature shares the common assumption of mobile capital, NEG models with tax competition have originally explored the case of labour mobility. Accordingly, seminal models can be classified according to whether they work under the assumption of labour (Ludema and Wooton 2000, Andersson and Forslid 2003) or capital/entrepreneur mobility (Kind et al. 2000; Baldwin and Krugman 2004; Ottaviano and Ypersele 2005; Borck and Pflüger 2006). Regardless differences in the mobility assumption - and other technical aspects - a general feature, as opposed to traditional tax competition outcomes, is that results depend on the degree of production agglomeration. Typically, when the mobile factor is concentrated, the associated the taxable rents imply that taxes will remain high without inducing relocation, provided that - in general - the international tax gap is smaller than the agglomeration rent.

Ludema and Wooton (2000) were the first to recognize the lack of theoretical work on the link between the two related issues arising from deeper economic integration: the erosion of fiscal autonomy experienced by integrating countries brought about by more mobile tax bases; and the spatial agglomeration of economic activity driven by divergent economic structures and incomes across the integrating countries. In motivating their interest in bringing together the two issues in a NEG framework, the authors explain the additional mechanism induced by international tax competition by which economic integration can have distributional consequences, thus providing the general rational at the core of the subsequent literature. That is, while agglomeration alters the distribution of income across countries, tax competition influences the distribution of income across factors. In Ludema and Wooton (2000) words, "if immobile factors compete to create or maintain a core by offering low (or negative) taxes to mobile manufacturing labor, they run the risk that much of the potential gain to having a core is dissipated in the process. If so, then agglomerative forces coupled with the tax competition may impoverish immobile factors, regardless of location" (Ludema and Wooton 2000, p. 333). For this reason, the question to be addressed is whether economic integration, by strengthening agglomerative forces, will intensify tax competition and will thus result in lower equilibrium taxes or not.

In order the answer to this question, Ludema and Wooton (2000) modify the Krugman (1991) model in two aspects. First, manufacturing firms are quantity-setting (Cournot) oligopolists, as opposed to the monopolistic competition approach commonly taken in NEG models. This departure allows obtaining closed-form solutions, while preserving all of the relevant characteristics of Krugman's model. Second, manufacturing workers are assumed to be imperfectly mobile. This assumption enables to study the effects of economic integration on the intensity of tax competition under two notions of international integration modelled as either an increase in factor mobility or as a reduction in trade costs on goods. They conclude that integration interpreted as decreasing trade costs reduces the intensity of tax competition, thus restoring rather than eroding fiscal autonomy. On the other hand, integration interpreted as increased labor mobility has mixed effects.

Andersson and Forslid (2003) use the Forslid and Ottaviano (1999) version of the Krugman (1991) model to study the effects of taxes on skilled and unskilled workers on the location of manufacturing production. In the model, proportional taxes on immobile unskilled workers and mobile skilled workers finance country-specific public goods. 
The authors study the impact of taxes on the stability of a dispersed equilibrium and find that it depends on the relationship between taxes on mobile labor and taxes on immobile labor. In particular, a small tax redistribution from mobile to immobile workers makes the dispersed equilibrium unstable, causing a catastrophic agglomeration where all skilled workers end up in one country. In line with Ludema and Woodon (2000), once the agglomeration is established and the related agglomeration rents arise, taxes on mobile workers are not generally driven down to some minimum in the "core" country as predicted by traditional tax competition.

As opposed to Ludema and Wooton (2000) and Andersson and Forslid (2003), Kind et al. (2000) investigate how spatial agglomeration of economic activity affects the outcome of capital tax competition in a NEG framework with mobile capital, thus obtaining results directly comparable with those obtained in the traditional literature on capital tax competition. They show that the outcome of tax competition depends on the interaction between two forces of agglomeration: trade costs and pecuniary externalities. The analysis considers the two alternative scenarios of capital (and firms) either concentrated in one single location or evenly distributed between two countries. When capital is concentrated in one single country, a government may be able to exploit the locational rents created by agglomeration forces through a positive source tax and this in turn will lead to an increase in national welfare. This result is in line with the conclusion of Ludema and Woodon (2000) as it shows that increased economic integration achieved via lower trade costs allows a country to raise its tax on mobile capital without losing productive resources. Indeed, since agglomeration makes capital effectively immobile due to pecuniary externalities, the host country gains from setting its source-tax on capital above that of the other country, thus increasing its welfare per capita. In the opposite case of industrial activities evenly spread across countries, the equilibrium outcome is such that both countries provide a subsidy of equal size to capital.

Perhaps the most well-known contribution in this field is the one by Baldwin and Krugman (2004), which challenges the idea that the integrating nations should agree on common tax rates in order to avoid the "race to the bottom" and undermine their relatively generous welfare states. Its popularity is probably due to two reasons. First, the policy implication it carries on the desirability of tax harmonization. Second, the capability it has to explain observed corporate tax differentials in integrating regions such as European Union in terms of external economies due to agglomeration forces. The results of Baldwin and Krugman (2004) are obtained within the solvable variant of the model of Krugman (1991) due to Forslid (1999), where the two otherwise identical countries have different tax rates. Entrepreneurs are the mobile factor, while workers are immobile. Agglomeration forces imply that the real reward of entrepreneurs includes a location specific agglomeration rent. That is, entrepreneurs located in the country that initially has the core strictly prefer to locate there and would thus be willing to bear a higher tax in order to be there. There exists a bell-shaped relationship between agglomeration rents (and tax rates that entrepreneurs are willing to pay) and trade openness. Indeed, when trade is impossible, firms cannot serve both markets from a single location and agglomeration is not possible. At the opposite extreme, when trade is completely free, location is irrelevant and agglomeration is useless. Hence, the importance of agglomeration is greatest (the tax rate the entrepreneurs is higher) 
at intermediate values of openness (where agglomeration is both feasible and useful). This implies that size of the locational rent is a bell-shaped function of the level of integration, so the tax gap first widens before narrowing as integration increases. From the policy perspective, the model delivers a result in sharp contrast with the traditional tax competition literature: harmonization makes one or both countries worse off when agglomeration forces are present.

Interestingly, Ottaviano and van Ypersele (2005) contribute to the tax competition and agglomeration literature by exploring three related issues. First, the distortions induced by tax competition on the international allocation of capital and, as a consequence, on the inefficient international specialization in production. Second, the subsequent inefficiencies caused to the pattern of international trade. Third, the impact of these inefficiencies on the gap in economic development among countries. According to the authors, the extant literature on tax competition and agglomeration - with the partial exception represented by Baldwin and Krugman (2004) - lacks a detailed welfare analysis able to reach a conclusion on the desirability of tax competition. Accordingly, they propose a full-fledge global welfare analysis in a general equilibrium model in which two countries compete for monopolistically competitive firms à la Ottaviano et al. (2002). Results are obtained using as a benchmark the free market outcome that yields a home market effect: the larger country hosts a more than proportionate share of firms. Unless trade costs are low enough, such an outcome is shown to be inefficient because it leads too many firms to concentrate in the larger country. In the tax competitive outcome, the location of firms is less concentrated than the free market one. When trade costs are large enough to make it inefficient for all firms to cluster in a single country, tax competition for mobile firms is efficiency-enhancing with respect to the free market outcome. This result is reversed as trade costs fall and clustering becomes efficient. Finally, under both free market and tax competition, the inefficiencies in international specialization and trade flows vanish when trade costs are low enough. Otherwise, only international tax coordination can implement the efficient spatial distribution of firms. All these results lead to conclude that "the policy attitude towards tax competition should depend on the degree of trade integration... at the initial stages of an integration process, forbidding tax competition without agreeing on tax coordination is a bad idea. It is much less so at later stages, when the free market and the harmonization outcomes tend to coincide" (Ottaviano and van Ypersele 2005, p. 45).

The models discussed above deal with variants of CP models with either symmetric equilibria or equilibria with complete agglomeration. Borck and Pflüger (2006) take one step forward and study whether the "race to the top" result suggested by previous work generalizes to a NEG framework, which features stable locational equilibria with only partial agglomeration of firms in one of two countries. The model draws on Pflüger (2004) $)^{5}$ and shows that, in addition to the extreme outcome of complete agglomeration, a tax differential may arise as an equilibrium of the tax game between the two countries even when there is only partial agglomeration. In particular, in the

${ }^{5}$ Pflüger (2004) develops a model that deviates from the standard CP model in two respects. First, it is assumed that the fixed cost in the manufacturing sector consists of a separate internationally mobile factor (Forslid 1999; Forslid and Ottaviano 2003). Second, the Cobb-Douglas upper-tier utility is replaced by a logarithmic quasi-linear utility specification. 
case with partial agglomeration, the partial core can maintain a positive tax gap even though no agglomeration rent accrues to the mobile factor.

\section{Trade: Unilateral Protectionism and Trade Agreements}

This section reviews trade policy implications of theoretical NEG models. We discuss unilateral actions of protection and liberalisation that aim at industrialisation, as well as trade agreements.

The most basic, symmetric NEG models yield a counter-intuitive result when it comes to unilateral protection. Import substitution in the form of unilateral protection always benefits the protecting region or nation (see for example Baldwin et al. 2003, Chap. 12). ${ }^{6}$ This so-called "price-lowering-protection" (PLP) mechanism works because the price-lowering inflow of firms into the home market exceeds the more direct price-increasing effect of protectionism. ${ }^{7}$ Therefore, it seems that unilateral protection is one strategy to gain welfare and attract industry. There are, however, some qualifications to be made.

The first one is the introduction of relocation costs. When it is costly for firms to change location, then unilateral protection has different impacts on the price index depending on (i) the costs of relocation, (ii) the trade openness of the respective nations and (iii) the relative strengths of agglomeration forces in the respective nations. The higher the costs for relocating, the more an unilateral protection will raise the price index because the offsetting inflow of firms does not take place. The level of relocation costs that prohibits the PLP is lower the easier it is to export to the foreign country and the stronger are the agglomeration forces in the home market. A second qualification to the PLP is the fact that a country has to be large enough for firms to have an incentive to relocate there. If the market size is too small, then unilateral protection will always raise the price index. Third, as long as factor endowments are assumed identical, there is no place for a comparative advantage (CA) story. Introducing such a Heckscher-Ohlin CA alters the PLP. Baldwin et al. (2003) assume different fixed costs across regions in order to model that. CA leads to a third effect of unilateral protection on the price index, the so-called "negative variety effect". Asymmetric trade barriers now have a negative effect on the total number of firms. While there exists no analytical solution to the model anymore, the authors are able to derive results for a special case. They find that the PLP does not work when CA is strong enough.

As Baldwin et al. (2003, p. 297) point out, the PLP clearly is an artefact of the specific model assumptions: "The notion that unilateral protection always lowers the domestic price level by enticing industry to relocate is certainly one of the most outlandish policy implications of simple economic geography models." They use the

\footnotetext{
${ }^{6}$ This chapter is in parts based on Puga and Venables (1997), Puga and Venables (1999) and Baldwin (1999). The political economy side of the discussion can for example be found in Baldwin and Robert-Nicoud (2007).

${ }^{7}$ Unilateral protection - represented as an increase in trade costs only in one direction - increases the price consumers have to pay for imported commodities, which involve a welfare loss similar to the one in standard models without factor mobility.
} 
vertical linkages version of the FC model to show that unilateral liberalisation can lead to industrialisation. On the one hand, liberalisation may lower the costs of imported intermediate goods, which in turn makes the liberalising country more attractive for firms. On the other hand, if it decreases the costs of shipping final goods to this country, it would make it less attractive as a location for firms. Hence, in order to attract some industry, a country would have to liberalise the intermediate goods market without affecting the final goods market. However, they also show that an across-the-board liberalisation could have a similar effect if the liberalising country is small and the other markets are relatively large and open.

What about comparative advantage? It can be shown that in models of economic geography, smaller, poorer countries might well be without industry despite the possible CA due to lower wages compared to the richer country. The presence of agglomeration effects can dominate any trade or location patterns that would result from CA. If this is the case, the effect is stronger, (i) the stronger are agglomeration forces, (ii) the more expensive trade is, (iii) the smaller the market of the smaller country, and (iv) the higher possible trade barriers imposed by richer industrialised countries against manufacturing goods from smaller poorer countries. All of the analysis above is based on the FC or the FCVL model that do not feature an endogenous market size (because capital income is remitted back to the - regionally immobile - capital owners). Allowing for an endogenous market size and thus introducing circular causality strengthens the argumentation.

A further topic in this discussion is tariffs and quotas. While they might be equivalent in the simpler trade model, they are not in NEG models. Tariffs and quotas might lead to relocation into the protecting country due to the "price-lowering-protection" (PLP) effect. However, the locational equilibrium differs between quotas and tariffs, which is due to the different recipients of the trade rents. A tariff is collected by the protecting nation (and paid out to its residents) while a quota shifts the trade rent to the exporting firm. Thus, the operating profit for a firm exporting under a quote is larger than for a firm that exports under a tariff. This in turn leads to a situation where firms exporting to the protecting nation are more likely to stay where they are. This also means that firms in the protecting nation (and the other for that matter) are more likely to lobby for quotas than for tariffs. This is because higher profits from a tariff would be driven to zero by firms that enter the protecting nation. A quota, therefore, has a smaller effect on the PLP because of less movement of firms and an increasing effect on profits in both trading regions.

Melitz and Ottaviano (2008) develop a model with firm heterogeneity to focus on the interplay of market size, firm productivity and firm location. Unilateral liberalisation of a country leads to a decrease in competition in the liberalising country and an increase in the other country, which is driven by the cost cut-off that determines if a firm is productive enough to produce in a given country. The cut-off increases due to the liberalisation. The change in competition means a welfare loss for the liberalising country and a welfare gain in the other country. This result only holds in the long run when firms enter markets, while the number of firms is fixed in the short run. In the short run an unilateral liberalisation first leads to a decrease of the cost cut-off resulting in a pro-competitive effect. The increase in varieties that are exported dominates the 
exit of local producers. To summarize, unilateral liberalisation first leads to an increase and then a decrease in welfare.

What the above discussion makes clear is that the welfare implications from more traditional trade models can be altered and even reversed when we consider NEG features such as the mobility of factors. While the price lowering protection effect is able to reverse the classical welfare implications, it very much depends on the specific model assumptions.

The second topic that we would like to review in this section on trade policy concerns the economic effects of preferential trade agreements. The standard analysis uses a Heckscher Ohlin model with two countries that form a union and a third, outside country. The union countries reduce mutual tariffs while maintaining the outside tariff, which leads to more specialisation within the union, creates additional trade between the countries of the union and diverts trade from the outside country to the countries inside the union. In a NEG perspective, the focus shifts from different countries (characterised by comparative advantages) to similar/identical countries and, in particular, factor mobility is possible. It turns out that - while the Heckscher-Ohlin results are still visible - NEG forces substantially alter the results. Note that for these questions multi-regional NEG models are indispensable. This stream of literature explicitly compares models with iso-elastic and with linear demand functions, where the latter as pointed out above - introduces an additional dispersion force via a variable mark-up.

An early account is found in Baldwin et al. (2003, Chap. 14), which is mainly based and expands on Puga and Venables (1997). The authors present a multiregional footloose capital model in which demand functions are iso-elastic and capital is mobile between all countries. Reducing internal tariffs, i.e. reducing internal trade costs, improves market access for manufacturing firms inside the union and factor rewards increase, which in turn attracts factors from the outside country to move into the union. A production shifting effect occurs: the manufacturing sector inside the union grows (due to factor migration). If countries inside the union are of different size, NEG agglomerative processes may lead to a core-periphery pattern with all the industry ending up in the bigger country. In addition, the authors explicitly address welfare issues: they show that welfare in the union increases, whereas it declines in the outside country. Monfort and Nicolini (2000) construct a two-country core-periphery model each of which consists of two regions, in which factor mobility occurs only within countries. The authors show that also in this model set up deeper integration inside both countries may trigger agglomeration processes. Interestingly, the authors find similar results for external trade liberalisation (similar also Monfort and Van Ypersele 2003). In a related paper, Commendatore et al. (2016) also use a footloose capital model with two countries inside a union and one outside country and two production sectors: agriculture that produces a homogenous commodity and manufacturing that produces differentiated commodities. In contrast, the demand functions are linear; and factor mobility occurs only within the union. Reducing internal trade costs again increases manufacturing factor rewards inside the union (via a better market access), which leads to a higher employment in manufacturing sector within the union. It is interesting to note that the manufacturing sector grows even if firm migration from the outside country is not possible. It grows because it attracts additional workers from the agricultural sector in each of the union countries. In this sense, the union specialises in 
manufacturing and - as a mirror image - the outside country specializes in agriculture. It leads to higher exports of the union, and to higher trade within the union. Integration, thus, leads to specialization, trade creation and trade diversion. These effects are similar to a Heckscher-Ohlin perspective. However, further reducing the trade costs may lead to a predominance of agglomeration forces within the union causing a core-periphery pattern of industrial activity. Competition is stronger in the newly formed core and given the linear demand functions - firms react by reducing the price and further increasing the output. Specialization of the union in the manufacturing sector is reinforced, and trade creation and trade diversion become stronger. Thus, NEG forces corroborate and modify the static Heckscher Ohlin assessment of integration areas.

Another stream of papers shifts the focus from internal integration to external trade liberalisation, i.e. to a reduction of trade costs between the union and the outside country. These studies stress that the impact w.r.t. regional inequalities in the union depends upon model specifications (see Brülhart 2011). A first group of models incorporates iso-elastic demand functions and thus constant mark-ups. The models typically assume that productive factors are mobile only within a country, but not between countries. A reduction of external trade costs increases market access for both countries within the union, agglomeration forces are strengthened, whereas competition from the other union country becomes less important. Thus, agglomeration force dominate and external trade liberalisation leads to internal agglomeration (see Paluzie 2001; Brülhart et al. 2004; Crozet and Koenig Soubeyran 2004; Commendatore et al. 2014). Finally, in a quite comprehensive study Zeng and Zhao (2010) study the interaction of internal integration, external liberalization and the degree of international factor mobility. They show that international factor mobility may actually reverse the results obtained with internationally immobile productive factors. A second group of models introduces additional dispersion forces: Krugman and Elizondo (1996) take into account that factor migration leads to an increase in land rentals and commuting costs; Behrens (2011) uses linear demand functions, which imply lower mark-ups if more competitors operate in the markets. This additional dispersion force may actually reverse the result: External liberalisation leads to internal dispersion instead of agglomeration. In a related paper, Behrens et al. (2007) study the interaction of a reduction in international and intranational trade costs. They show that "lower intranational transport costs foster regional divergence when international trade costs are high enough, whereas lower international trade costs promote regional convergence when intranational transport costs are high enough" (Behrens et al. 2007, p. 1297).

\section{References}

Ago, T., Isono, I., Tabuchi, T.: Locational disadvantage of the hub. Ann. Reg. Sci. 40, 819-848 (2006)

Andersson, F., Forslid, R.: Tax competition and economic geography. J. Public Econ. Theor. 5, 279-303 (2003)

Bagoulla, C.: Localisation industrielle et spécialisation. Rev. Économique 57, 705-726 (2006)

Baldwin, R.: Nontariff Distortions of International Trade. Brookings Institution, Washington, DC (1970) 
Baldwin, R.: Trade policies in developed countries. In: Jones, R., Kenen, P. (eds.) Handbook of International Economics. Elsevier North-Holland (1984)

Baldwin, R., Krugman, P.: Agglomeration, integration and tax harmonization. Eur. Econ. Rev. 48, 1-23 (2004)

Baldwin, R., Forslid, R., Martin, P., Ottaviano, G., Robert-Nicoud, F.: Economic Geography and Public Policy. Princeton University Press, Princeton (2003)

Baldwin, R.E., Okubo, T.: International trade, offshoring and heterogeneous firms. Rev. Int. Econ. 22, 59-72 (2014)

Baldwin, R.E., Robert-Nicoud, F.: Entry and asymmetric lobbying: why governments pick losers. J. Eur. Econ. Assoc. 5, 1064-1093 (2007)

Baldwin, R.E., Martin, P.: Agglomeration and regional growth. In: Henderson, J.V., Thisse, J.F. (eds.) Handbook of Regional and Urban Economics. Cities and Geography, vol. 4. Elsevier North-Holland (2004)

Baldwin, R.E., Okubo, T.: Heterogeneous firms, agglomeration and economic geography: spatial selection and sorting. J. Econ. Georg. 6, 323-346 (2006)

Baldwin, R.E.: Agglomeration and endogenous capital. Eur. Econ. Rev. 43, 253-280 (1999)

Behrens, K.: International integration and regional inequalities: how important is national infrastructure? Manchester School 79, 952-971 (2011)

Behrens, K., Gaigné, C., Ottaviano, G.I.P., Thisse, J.-F.: Countries, regions and trade: on the welfare impacts of economic integration. Eur. Econ. Rev. 51, 1277-1301 (2007)

Borck, R., Pflüger, M.: Agglomeration and tax competition. Eur. Econ. Rev. 50, 647-668 (2006)

Brakman, S., Garretsen, H., Van Marrewijk, C.: An Introduction to Geographical Economics. Cambridge University Press, Cambridge (2001)

Brakman, S., Garretsen, H., Van Marrewijk, C.: Location competition and agglomeration: the role of government spending. CESifo Working Paper No. 775, München (2002)

Brakman, S., Garretsen, J.H., Marrewijk, J.G.M.: Agglomeration and government spending. In: Brakman, S., Garretsen, H. (eds.) Foreign Direct Investment and the Multinational Enterprise. MIT Press (2008)

Breinlich, H., Ottaviano, G.I.P., Temple, J.R.W.: Regional growth and regional decline. In: Philippe, A., Steven, N.D. (eds.) Handbook of Economic Growth. Elsevier (2014)

Brülhart, M., Trionfetti, F.: Public expenditure, international specialisation, and agglomeration. Eur. Econ. Rev. 48, 851-881 (2004)

Brülhart, M.: The spatial effects of trade openness: a survey. Rev. World Econ. 147, 59-83 (2011)

Brülhart, M., Crozet, M., Koenig, P.: Enlargement and the EU periphery: the impact of changing market potential. World Econ. 27, 853-875 (2004)

Cerina, F., Pigliaru, F.: Agglomeration and growth: a critical assessment. In: Fingleton, B. (ed.) New Directions in Economic Geography. Edward Elgar, Cheltenham (2007)

Cerina, F., Mureddu, F.: Agglomeration and growth with endogenous expenditure shares. J. Reg. Sci. 52, 324-360 (2012)

Charlot, S., Gaigné, C., Robert-Nicoud, F., Thisse, J.-F.: Agglomeration and welfare: the coreperiphery model in the light of Bentham, Kaldor, and Rawls. J. Publ. Econ. 90, 325-347 (2006)

Commendatore, P., Kubin, I.: Source versus residence: a comparison from a new economic geography perspective. Pap. Reg. Sci. 95, 201-223 (2016)

Commendatore, P., Kubin, I., Mossay, P.: On the new economic geography of a multi-cone world. Rev. Int. Econ. (2017). doi:10.1111/roie.12312, forthcoming

Commendatore, P., Kubin I., Sushko, I.: Trade agreements in a linear FE model. In: Bednar-Friedl, B., Kleinert, J. (eds.) Dynamic Approaches to Global Economic Challenges. Festschrift in Honor of Karl Farmer. Springer International Publishing (2016) 
Commendatore, P., Filoso, V., Grafeneder-Weissteiner, T., Kubin, I.: Towards a multiregional neg framework: comparing alternative modelling strategies. In: Commendatore, P., Kayam, S., Kubin, I. (eds.) Complexity and Geographical Economics, Dynamic Modeling and Econometrics in Economics and Finance. Springer International Publishing, Cham (2015)

Commendatore, P., Kubin, I., Petraglia, C.: Productive public expenditure in a new economic geography model. Économie Int./Int. Econ. 114, 133-160 (2008)

Commendatore, P., Kubin, I., Petraglia, C.: Footloose capital and productive public services. In: Salvadori, N., Commendatore, P., Tamberi, M. (eds.) Geography, Structural Change and Economic Development: Theory and Empirics. Edward Elgar Publishing (2009)

Commendatore, P., Kubin, I., Petraglia, C.: R\&D public expenditure, knowledge spillovers and agglomeration: comparative statics and dynamics. In: Chiarella, C., Bischi, G.I., Gardini, L. (eds.) Nonlinear Dynamics in Economics, Finance and the Social Sciences. Springer, Heidelberg (2010)

Commendatore, P., Kubin, I., Petraglia, C., Sushko, I.: Regional integration, international liberalisation and the dynamics of industrial agglomeration. J. Econ. Dyn. Control 48, 265287 (2014)

Cronon, W.: Nature's Metropolis: Chicago and the Great West. WW Norton \& Company (1991)

Crozet, M., Koenig Soubeyran, P.: EU enlargement and the internal geography of countries. J. Comp. Econ. 32, 265-279 (2004)

Desmet, K., Rossi-Hansberg, E.: On spatial dynamics. J. Reg. Sci. 50, 43-63 (2010)

Desmet, K., Rossi-Hansberg, E.: Spatial development. Am. Econ. Rev. 104, 1211-1243 (2014)

Desmet, K., Rossi-Hansberg, E.: Spatial growth and industry age. J. Econ. Theor. 144, 24772502 (2009)

Dupont, V.: Do geographical agglomeration, growth and equity conflicts? Pap. Reg. Sci. 86, 193-213 (2007)

Dupont, V., Martin, P.: Subsidies to poor regions and inequalities: some unpleasant arithmetic. J. Econ. Geogr. 6, 223-240 (2006)

Forslid, R., Wooton, I.: Comparative advantage and the location of production. Rev. Int. Econ. 11, 588-603 (2003)

Forslid, R., Ottaviano, G.: An analytically solvable core-periphery model. J. Econ. Geogr. 3, 229-240 (2003)

Forslid, R.: Regional policy, integration and the location of industry in a mutiregion framework, CEPR discussion paper No 4630, London (1994)

Forslid, R.: Agglomeration with human and physical capital: an analytically solvable case, CEPR Discussion Paper No. 2102, London (1999)

Forslid, R., Ottaviano, G.I.P.: Trade and Agglomeration: An Analytically Solvable Case. Mimeo, Lund University (1999)

Fujita, M., Thisse, J.-F.: Economics of Agglomeration. Cities, Industrial Location and Regional Growth. Cambridge University Press, Cambridge (2002)

Fujita, M., Mori, T.: The role of ports in the making of major cities: self-agglomeration and hub-effect. J. Dev. Econ. 49, 93-120 (1996)

Fujita, M., Mori, T.: Frontiers of the new economic geography. Pap. Reg. Sci. 84, 377-405 (2005)

Grafeneder-Weissteiner, T., Kubin, I., Prettner, K.: Coping with inefficiencies in a new economic geography model: the unintended consequences of policy interventions. Math. Soc. Sci. 76, 146-157 (2015)

Grossman, G.M., Helpman, E.: Quality ladders in the theory of growth. Rev. Econ. Stud. 58, 43$61(1991)$

Kind, H., Midelfart-Knarvik, K., Schjelderup, G.: Competing for capital in a "lumpy" world. J. Publ. Econ. 78, 253-274 (2000) 
Krugman, P., Elizondo, R.L.: Trade policy and the third world metropolis. J. Dev. Econ. Increasing Returns Monopolistic Competition Econ. Dev. 49, 137-150 (1996)

Krugman, P.: Increasing returns and economic geography. J. Polit. Econ. 99, 483-499 (1991)

Krugman, P.: Geography and Trade. MIT Press, Cambridge (1992)

Krugman, P.: First nature, second nature, and metropolitan location. J. Reg. Sci. 33, 129-144 (1993)

Krugman, P.R., Venables, A.J.: Globalization and the inequality of nations. Q. J. Econ. 110, 857-880 (1995)

Ludema, R.D., Woodon, I.: Economic geography and the fiscal effects of regional integration. J. Int. Econ. 52, 331-357 (2000)

Martin, P., Rogers, C.A.: Industrial location and public infrastructure. J. Int. Econ. 39, 335-351 (1995)

Martin, P., Ottaviano, G.I.P.: Growing locations: industry location in a model of endogenous growth. Eur. Econ. Rev. 43, 281-302 (1999)

Martin, P.: Can regional policies affect growth and geography in Europe? World Econ. 21, 757 774 (1998)

Martin, P.: Public policies, regional inequalities and growth. J. Public Econ. 73, 85-105 (1999)

Matsuoka, Y., Kikuchi, T.: Footloose capital and comparative advantage. Pac. Econ. Rev. 17, 677-686 (2012)

Matsuyama, K., Takahashi, T.: Self-defeating regional concentration. Rev. Econ. Stud. 65, 211234 (1998)

Melitz, M.J., Ottaviano, G.I.P.: Market size, trade, and productivity. Rev. Econ. Stud. 75, 295316 (2008)

Melitz, M.J.: The impact of trade on intra-industry reallocations and aggregate industry productivity. Econometrica 71, 1695-1725 (2003)

Monfort, P., Nicolini, R.: Regional convergence and international integration. J. Urban Econ. 48, 286-306 (2000)

Monfort, P., Van Ypersele, T.: Integration, Regional Agglomeration and International Trade, CEPR Discussion Paper No. 3752, London (2003)

Okubo, T.: Trade liberalisation and agglomeration with firm heterogeneity: forward and backward linkages. Reg. Sci. Urban Econ. 39, 530-541 (2009)

Okubo, T., Picard, P.M., Thisse, J.-F.: The spatial selection of heterogeneous firms. J. Int. Econ. 82, 230-237 (2010)

Østbye, S.: Regional policy analysis in a simple general equilibrium model with vertical linkages. J. Reg. Sci. 50, 756-775 (2010)

Ottaviano, G.I.P., van Ypersele, T.: Market size and tax competition. J. Int. Econ. 67, 25-47 (2005)

Ottaviano, G.I.P., Tabuchi, T., Thisse, J.-F.: Agglomeration and trade revisited. Int. Econ. Rev. 43, 409-435 (2002)

Ottaviano, G.I.P., Thisse, J.-F.: On economic geography in economic theory: increasing returns and pecuniary externalities. J. Econ. Geogr. 1, 153-179 (2001)

Ottaviano, G.I.P., Thisse, J.-F.: Integration, agglomeration and the political economics of factor mobility. J. Public Econ. 83, 429-456 (2002)

Ottaviano, G.I.P.: Monopolistic competition, trade, and endogenous spatial fluctuations. Reg. Sci. Urban Econ. 31, 55-77 (2001)

Ottaviano, G.I.P.: "New" new economic geography: firm heterogeneity and agglomeration economies. J. Econ. Geogr. 11, 231-240 (2011)

Ottaviano, G.I.P.: Agglomeration, trade and selection. Reg. Sci. Urban Econ. 42, 987-997 (2012)

Paluzie, E.: Trade policy and regional inequalities. Papers Reg. Sci. 80, 67-85 (2001) 
Pflüger, M., Tabuchi, T.: Comparative Advantage and Agglomeration of Economic Activity, IZA Discussion Paper No. 10273, Bonn (2016)

Pflüger, M., Südekum, J.: Integration, agglomeration and welfare. J. Urban Econ. 63, 544-566 (2008)

Pflüger, M.: A simple, analytically solvable Chamberlinian agglomeration model. Reg. Sci. Urban Econ. 34, 565-573 (2004)

Picard, P.M., Zeng, D.-Z.: A harmonization of first and second natures. J. Reg. Sci. 50, 973-994 (2010)

Puga, D., Venables, A.J.: Preferential trading arrangements and industrial location. J. Int. Econ. 43, 347-368 (1997)

Puga, D., Venables, A.J.: Agglomeration and economic development: import substitution vs. trade liberalisation. Econ. J. 109, 292-311 (1999)

Ricci, A.L.: Economic geography and comparative advantage: agglomeration versus specialization. Eur. Econ. Rev. 43, 357-377 (1999)

Romer, P.M.: Endogenous technological change. J. Polit. Econ. 98, S71-S102 (1990)

Roos, M.W.M.: How important is geography for agglomeration? J. Econ. Geogr. 5, 605-620 (2005)

Tabuchi, T., Thisse, J.-F.: Taste heterogeneity, labor mobility and economic geography. J. Dev. Econ. 69, 155-177 (2002)

Trionfetti, F.: Public expenditure and economic geography. Ann. d'Économie et de Stat. 47, 101120 (1997)

Trionfetti, F.: Public procurement, market integration, and income inequalities. Rev. Int. Econ. 9, 29-41 (2001)

Venables, A.J.: Shifts in economic geography and their causes. Econ. Rev. Fed. Reserve Bank Kansas City 91, 61-85 (2006)

Venables, A.J.: Equilibrium locations of vertically linked industries. Int. Econ. Rev. 37, 341-359 (1996)

Zeng, D.-Z., Zhao, L.: Globalization, interregional and international inequalities. J. Urban Econ. 67, 352-361 (2010)

Open Access This chapter is licensed under the terms of the Creative Commons Attribution 4.0 International License (http://creativecommons.org/licenses/by/4.0/), which permits use, sharing, adaptation, distribution and reproduction in any medium or format, as long as you give appropriate credit to the original author(s) and the source, provide a link to the Creative Commons license and indicate if changes were made.

The images or other third party material in this chapter are included in the chapter's Creative Commons license, unless indicated otherwise in a credit line to the material. If material is not included in the chapter's Creative Commons license and your intended use is not permitted by statutory regulation or exceeds the permitted use, you will need to obtain permission directly from the copyright holder.

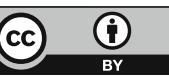

